\title{
A System Dynamics Model of the Community-Based Rural Drinking Water Supply Program (PAMSIMAS) in Indonesia
}

\author{
D. Daniel $1,2, *(1)$, Julivius Prawira ${ }^{3}$, Trimo Pamudji Al Djono ${ }^{4}$, S. Subandriyo ${ }^{5}$, Arya Rezagama ${ }^{6}$ and
} Aries Purwanto 7 (1)

check for updates

Citation: Daniel, D.; Prawira, J.; Al

Djono, T.P.; Subandriyo, S.;

Rezagama, A.; Purwanto, A. A System Dynamics Model of the Community-Based Rural Drinking Water Supply Program (PAMSIMAS) in Indonesia. Water 2021, 13, 507. https://doi.org/10.3390/w13040507

Academic Editor: Oz Sahin

Received: 15 January 2021

Accepted: 12 February 2021

Published: 15 February 2021

Publisher's Note: MDPI stays neutral with regard to jurisdictional claims in published maps and institutional affiliations.

Copyright: (C) 2021 by the authors Licensee MDPI, Basel, Switzerland. This article is an open access article distributed under the terms and conditions of the Creative Commons Attribution (CC BY) license (https:/ / creativecommons.org/licenses/by/ $4.0 /)$.
1 Department of Water Management, Faculty of Civil Engineering and Geosciences, Delft University of Technology, 2628 CN Delft, The Netherlands

2 Department of Health Behavior, Faculty of Medicine, Public Health and Nursing, Universitas Gadjah Mada, Environment, and Social Medicine, Yogyakarta 55281, Indonesia

3 Department of Engineering and Policy Analysis, Faculty of Technology, Policy and Management, Delft University of Technology, 2628 BX Delft, The Netherlands; juliviusprawira@student.tudelft.nl

4 Department of Environmental Engineering, Sekolah Tinggi Teknologi Sapta Taruna, Jakarta 13340, Indonesia; aldjono@gmail.com

5 The Community-Based Rural Water Supply and Sanitation Program (PAMSIMAS), Magelang Regency, Mungkid 56511, Indonesia; bandriyosalatiga@gmail.com

6 Department of Environmental Engineering, Diponegoro University, Semarang 50275, Indonesia; arya_tl@ft.undip.ac.id

7 Department of Land and Water Management, IHE Delft Institute for Water Education, 2611 AX Delft, The Netherlands; a.purwanto@un-ihe.org

* Correspondence: d.daniel@tudelft.nl or danielhombing@gmail.com
Abstract: The sustainability of the water supply program in developing countries is influenced by many inter-linked and dynamic factors, suggesting the need to analyse the system behaviour of the water supply program. However, no study analyses factors influencing the sustainability of rural drinking water supply programs holistically, and this study aims to fill that gap. This study utilized a system dynamics approach based on a case study of a community-based rural drinking water supply program (PAMSIMAS in Bahasa) in Magelang Regency, Indonesia. Five sustainability aspects were considered in the model development and simulation: financial, institutional, environmental, technical, and social aspects. Eight scenario analyses related to those five aspects were conducted. The causal loop diagrams suggest that the overall loop in the system is reinforcing, meaning that the improvement in one aspect will improve the overall condition of the system and deterioration in one aspect will reduce the overall condition of the system. Scenario analysis shows that external fund is critical to support the program financially, especially at the beginning of the project when the piped system is being built and water revenue is still low. Scenario and sensitivity analyses revealed that human factors, i.e., the performance of the water board and response and support from the community, positively influence the sustainability of the water supply program. Additionally, the water board plays a key role in accelerating the pipe network growth. Finally, this paper argues that visualising and simulating the causal relationship and dynamic behaviour of the rural water supply program are critical for water stakeholders to better design and implement the water supply program.

Keywords: rural drinking water supply; system dynamics; Indonesia; PAMSIMAS; sustainability

\section{Introduction}

There were still 785 million or $11 \%$ of the total global population lacking basic water services, i.e., the water is taken from improved sources and the collection time is less than half an hour for a roundtrip, in 2017 [1,2]. The majority of those lacking basic services lived in rural areas, which points to the inequalities in water services between urban and rural areas. In addition, water shortage is rapidly increasing worldwide, which is believed to worsen the situation [3]. These situations hamper the achievement of the Sustainable 
Development Goal (SDG) 6.1, i.e., to "achieve universal and equitable access to safe and affordable drinking water for all" by 2030 [2].

Indonesia is still struggling to improve the access to basic water services. According to the WHO/UNICEF Joint Monitoring Programme (JMP) report in 2017, nine out of ten households in Indonesia had at least basic water services. In terms of inequalities between urban and rural areas, about $95 \%$ of households in urban had access to basic water services compared to $82 \%$ in rural areas [1]. While the percentage of access to the basic water services increased only $5 \%$ in urban areas, there was a significant increase in rural areas $(16 \%)$ during the period of 2000-2017.

The Government of Indonesia and the World Bank initiated the community-based drinking water supply and sanitation program, called "Program Penyediaan Air Minum dan Sanitasi Berbasis Masyarakat (PAMSIMAS)", in 2007 to increase the coverage of water and sanitation services especially in peri-urban and rural areas [4]. PAMSIMAS benefited about 17.2 million people throughout Indonesia until 2018 [5]. The PAMSIMAS project is carried out at the village level and organized by a village water board committee, which is called "KPSPAMS" in Bahasa, that is responsible for planning, operationalizing and maintaining the pipe system. Therefore, the performance of the water board is very critical to ensure the sustainability of the project [6]. In this study, sustainability means the continuation of tap water services over a long period [7].

Five sustainability aspects are "required" to sustain PAMSIMAS projects, i.e. Financial, Institutional, Environmental, Technical, and Social (FIETS) [8,9]. Moreover, previous studies have identified such critical pathways or combinations of factors that influence the sustainability of rural water supply programs in the developing countries, in which all these factors are closely related to those FIETS aspects $[10,11]$.

By considering the complexity of the water, sanitation, and hygiene (WASH) projects and a wide range of interconnected factors influencing the project's outcome, Valcourt et al. [12] argue that WASH is a "complex" system and that a "system thinking approach" is needed to analyse the sustainability of the WASH projects, including the rural water supply projects in the developing countries. In the complex system domain, interactions among variables or factors in the form of feedback, either positive or negative, have to be carefully analysed to understand the dynamic of the system [13]. This feedback is considered as a chain of cause and effect relationship in which the changes in one variable result in the changes in all subsequent variables and then change the overall system behaviour or condition. The system behaviour can be dynamic, nonlinear, and unpredictable [14].

One of the methods to perform the system approach is system dynamics (SD) modelling [14]. SD was first introduced by Jay W. Forrester in 1961 [15]. SD modelling can be used to visualise a behaviour of the complex system, illustrate the trade-offs, and simulate and test alternative policies [16]. The basic form of SD modelling is a causal loop diagram (CLD); this is the qualitative aspect of the SD modelling and portrays the causal effect relationships among variables in a system, i.e., how each factor influences each other factor and then the whole system [16]. CLD is useful to aid stakeholders with less technical knowledge in understanding a complex system [17]. On the other hand, a stock and flow diagram (SFD) is the quantitative aspect of the SD modelling with accompanying equations that could be made based on the CLD structure. SFD aims to quantify the causal effect relationships in the system. CLD and SFD are common tools in the SD modelling or system thinking approach $[14,16]$. Purwanto et al. [18] argue that CLD and SFD are complementary and can provide a holistic approach to investigate complex phenomena. As such, SD modelling is one of the promising and useful approaches in applying the system thinking approach in the context of WASH domain or rural water supply projects.

Despite its benefits, there are only a few studies that utilise SD modelling in understanding the sustainability of water supply projects in rural areas. Some of them use only CLD or the qualitative approach $[11,14,19,20]$, while others use both CLD and SFD, i.e., qualitative and quantitative approaches [21,22]. Unfortunately, previous studies do not consider the FIETS sustainability aspects in their SD models. For instance, there are no 
social and institutional-related factors discussed in the model, despite their critical roles in the community-based drinking water program [23]. In addition, there is no study on the sustainability of water supply projects in Indonesia although this topic is necessary to support the achievement of SDG 6.1 in this country.

Therefore, the objective of this study is to assess the influence of the driving factors of the sustainability of the community-based rural drinking water supply program using a case study in Magelang Regency, Indonesia. Magelang is a landlocked regency in the province of Central Java, Indonesia, and is surrounded by six other regencies (Figure 1). Magelang Regency covers an area of $1085 \mathrm{~km}^{2}$ and consists of 21 sub-districts and 372 villages. The altitude of Magelang Regency ranges from 208 to 1378 m.a.s.l. The rainy season usually occurs from November to April (6 months), and there is relatively little rain from July until September (4 months). The average rainfall in 2019 was $2593 \mathrm{~mm}$ [24]. The household percentage of access to the tap water and access to the basic sanitation in Magelang Regency in 2019 was $95 \%$ and $97 \%$ respectively [25]. PAMSIMAS project started in 2008 and has reached 200 villages in Magelang Regency [26].

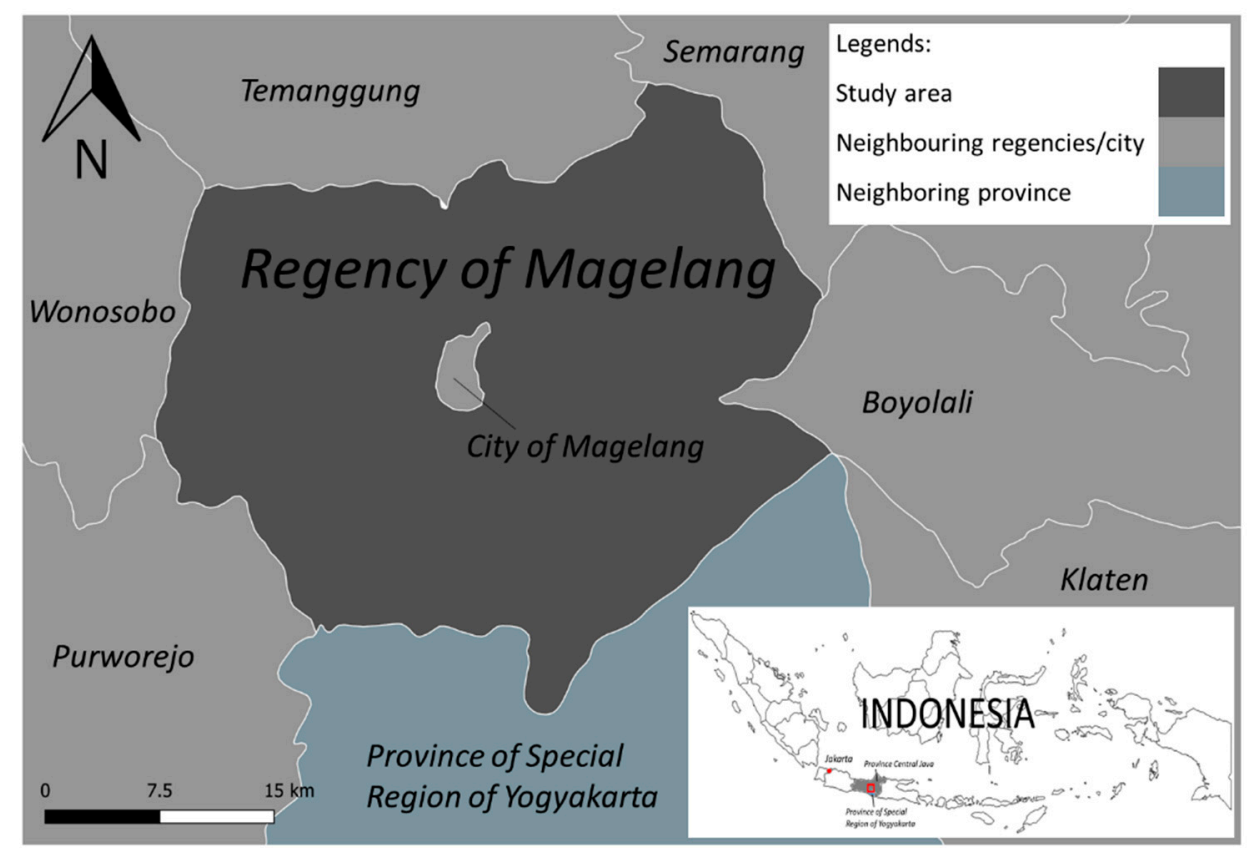

Figure 1. The study area of Magelang Regency. The map was drawn using QGIS ver. 3.4.15-Madeira (qgis.org).

\section{The Causal Loop Diagram (CLD) of the PAMSIMAS}

CLD comprises variables, arrows, and polarity signs. The arrows indicate the hypothesised cause-effect relationship between variables. The effect can be either a positive polarity sign, i.e., the increase of the cause variable will increase the affected variable, or a negative polarity sign, i.e., the increase of the cause variable will decrease the affected variable. The connection among several connected variables can create a closed cycle, which is called a feedback loop. The feedback loop can be either "reinforcing" (R), where the overall cause-effect relationships will make the system either grow or slow down, or "balancing" (B), where the overall cause-effect relationships will stabilize the system. Another important notation in CLD is a delay in which the affected variable responds slowly to the changes in the cause variable [13].

The CLD was inspired by the previous PAMSIMAS study in Karanganyar Regency, Central Java Province [27]. The structure was then upgraded by including variables and causal connections that are relevant to Magelang Regency. The structure was confirmed internally among authors who are familiar with PAMSIMAS projects. Variables used in the CLD incorporated the five FIETS aspects of sustainability, e.g., community characteristics 
that represent the social aspect and water board performance, which is related to the institutional aspect.

The complete CLD is shown in Figure 2. It shows the important elements and hypothetical cause-effect flow in the system. There are four main loops of sub-model in the CLD, i.e., "R1-R3" (reinforcing) and " $B$ " (balancing). The CLD indicates that the overall loop in PAMSIMAS is reinforcing, i.e., the increase of one variable will increase the value of the subsequent variables and the overall conditions of the system, and vice-versa for decreases in one variable.

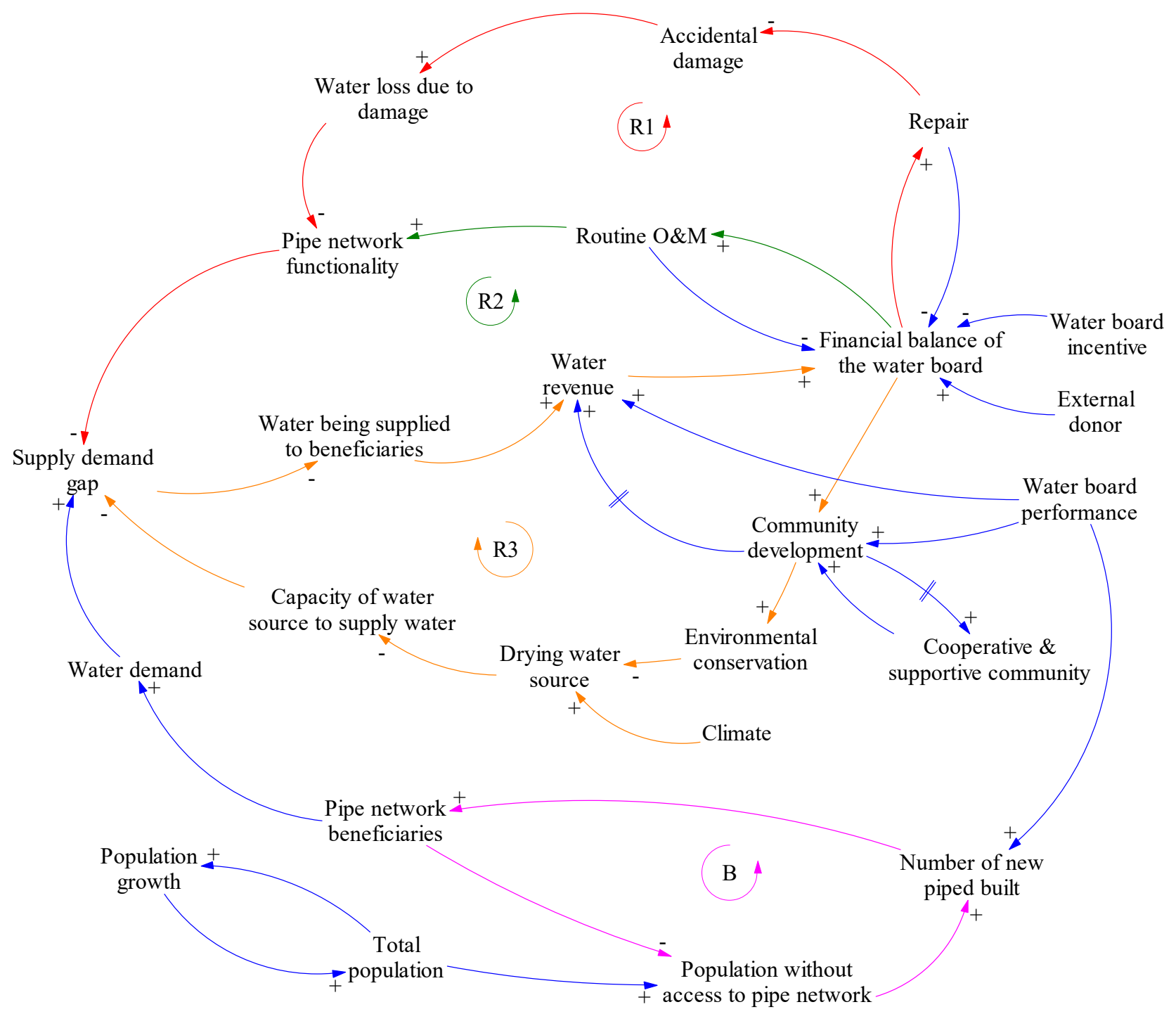

Figure 2. Causal loop diagram of the rural water supply network (PAMSIMAS).

The inclusion of many variables in CLD suggests that the sustainability of communitybased rural drinking water supply program in developing countries is indeed complex. It involves not only financial or technical aspects but also variables related to social, institutional, and environmental aspects.

The CLD shows that the financial balance of the water board is positively influenced by water revenue (paid by the beneficiaries) and external donors. On the other hand, financial expenses are for water board incentives, repair, operation \& maintenance (O\&M), and community development. Moreover, the water revenue is influenced by the amount of water being consumed by beneficiaries, community development, and water board performance. 


\subsection{Sub-System R1 (Damage) and R2 (OEM): Physical Infrastructure}

The loops of the sub-models R1 and R2 are reinforcing (Figure 3). A well-functioning water pipe network will reduce the supply-demand water gap in the community. Besides, the more the community receives the water, the more water fee is being paid, and this will positively influence the financial condition of the water board and the implementation of O\&M and repair.

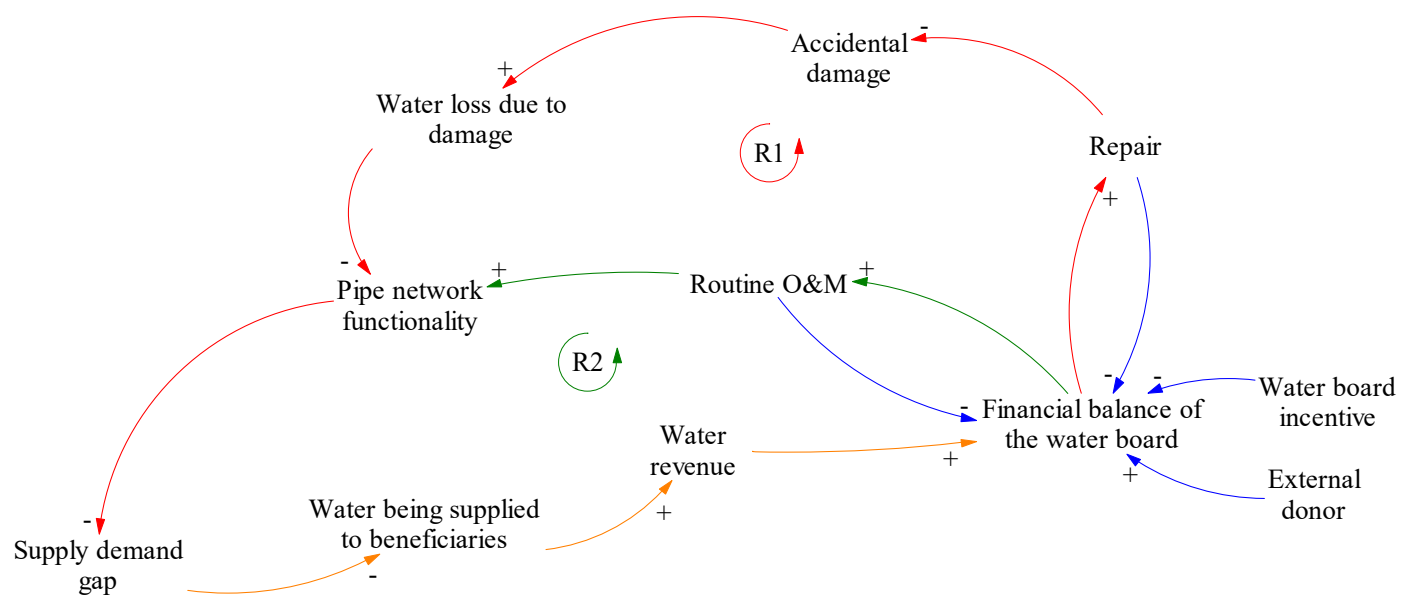

Figure 3. Causal loop diagram of the sub-models R1 and R2.

Two factors influence the pipe network functionality: accidental and deliberate damage (R1) and routine O\&M (R2). These two loops are separated in the CLD. The loop R1 focuses on the accidental and deliberate damage that results in water loss in the system and then influences the pipe network functionality. This accidental damage, for example, pipe stealing, damage by a wild animal, flooding, and landslide, could not be prevented or minimised by O\&M measures. These kind of damages have occurred several times in that area. Hence, the assumption in the sub-model R1 that was further used in the SFD is that the O\&M does not influence the occurrence of accidental damage in the water supply network and should be separated in the SFD. Furthermore, the reduction of pipe network functionality will then influence the water revenue and financial balance of the water board. The lack of money will make the water board unable to carry out optimal repairs.

On the other hand, loop R2 shows how the good financial condition of the water board will positively influence the routine O\&M and the functionality of the pipe network. However, more routine O\&M activities, such as the increasing number of pipe networks to be maintained and the frequency of the maintenance, will negatively burden the financial condition.

The CLD also implies that the income for the water board not only comes from the water revenue paid by the beneficiaries but also comes from external donors, such as village funds or external grants. Finally, the main expenses of the water board in sub-models R1 and $\mathrm{R} 2$ cover repair cost, O\&M cost, and water board incentive.

\subsection{Sub-System R3: Financial and Community Development}

The loop of the sub-model financial—community development is reinforcing (Figure 4). PAMSIMAS requires specific budget allocation in the water board balance for community development. In this paper, we define community development as the willingness and ability of the community to support or participate in the PAMSIMAS project. The availability of the water board budget will positively influence community development through the engagement of the community to undertake environmental conservation activities (water recharge area treatment, tree planting, etc.). These actions will indirectly improve the replenishment process of the water sources. 


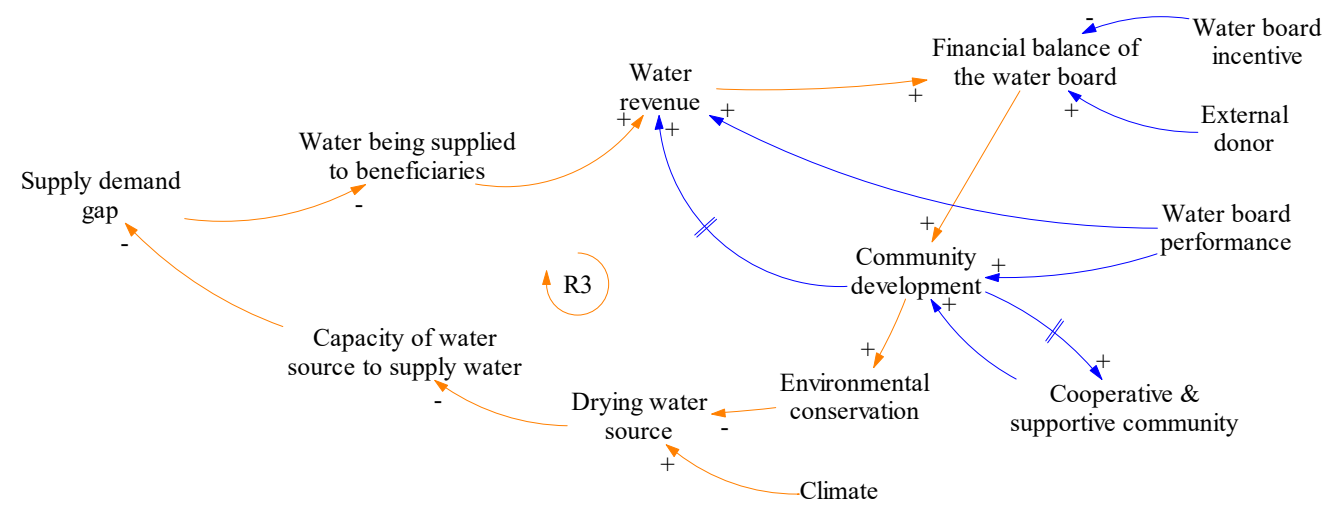

Figure 4. Causal loop diagram of the sub-model financial—community development.

However, based on the field experience, it can be stated that the availability of a budget is not a single factor that significantly influences community development. There are two other important factors: (1) water board performance and (2) characteristics of the community to support or not to support the program.

From the field experience, we found that water board performance is not influenced by the incentive that they received. That is because the incentive is relatively small and, usually, working on the water board is voluntary. The water board members are often found still doing their jobs, e.g., doing the maintenance and repairing broken pipes, without any financial incentive due to insufficient money in the water board finance. In PAMSIMAS, the water board is responsible for community development in the project area. Hence, a well-performing water board positively influences the community development program.

On the other hand, the character of the community, i.e., community attitude, is another variable that does influence the success of community development. A cooperative and supportive community facilitates community development, and positive development will reinforce the community characteristic. However, this process is relatively slow, i.e., there is a delay from community development to the community characteristic.

Another important finding is that not all beneficiaries pay the water fee. Important reasons for that are the trust of the community in the water board, i.e., the water board, and the characteristics of the community, i.e., the community. The low trust from the community could be caused by lack of transparency or misuse of the water board budget or the frequent delay of the damage repair. There are uncooperative and unsupportive people who want to get water but do not want to or are late to pay. Community development could change this perception, but it often takes quite some time. Therefore, there is a delay from community development to water revenue.

As mentioned previously, community development will positively influence the environmental conservation and then reduce the effect of the drought of water source in the dry season (variable "climate" in the CLD), i.e., so that there is still enough water being supplied to all beneficiaries. Furthermore, the amount of water consumed by the beneficiaries will affect the financial balance and then influence on the community development.

The loop R3 also indicates that the water revenue may vary depending on the season. If the water source dries up in the dry season, it will reduce the amount of supplied water and then the water revenue. This finding indicates that community development (or environmental conservation) is critical to sustaining the water board finance in the dry season.

\subsection{Sub-System B: Population and Water Demand}

The last sub-model consists of variables associated with the number of population, the number of new piped built, and the total water demand (Figure 5). PAMSIMAS regulation requires that water be distributed to the beneficiaries at the end of the first year of the project, either part or all of the targeted beneficiaries. Hence, it is often that not all targeted beneficiaries receive the water. Based on the field experience in that area, only $25 \%$ of the 
targeted beneficiaries have access to the water at the end of the first year and 5 years is usually needed to reach all the targeted beneficiaries. It means that there is an incremental growth in the pipe network growth. The pipe network growth ("number of new piped built" in the CLD) is positively influenced by the water board performance and population without access to the pipe network.

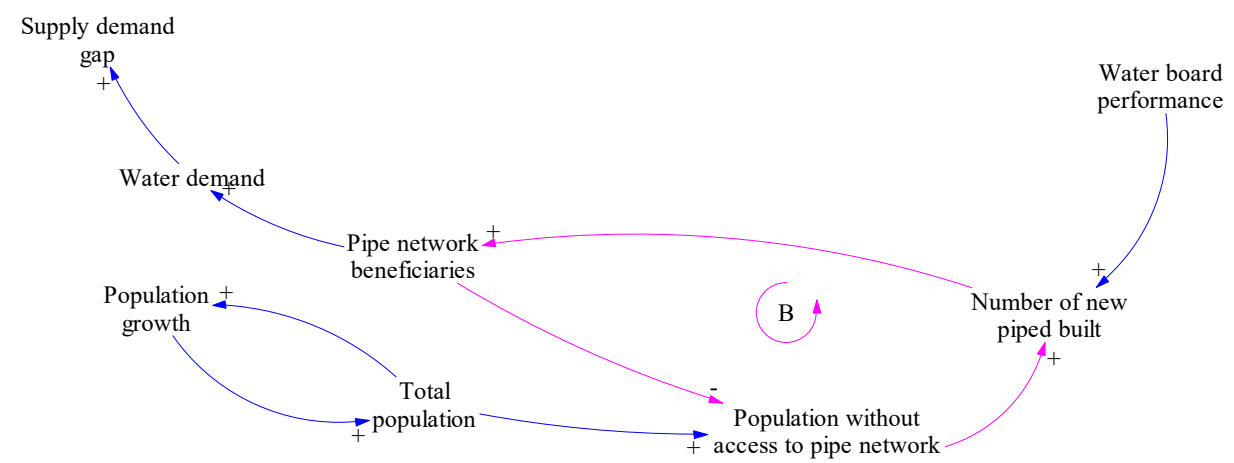

Figure 5. Causal loop diagram of the sub-model population and water demand.

Based on field observations, the water board plays an important role in the development of the new pipeline. Having passionate water board members results in faster completion of the whole pipe network.

Additionally, the pipe network growth will increase the beneficiaries and thus the total amount of water supply to all beneficiaries but will decrease the population without access to the pipe network. The population without access to the pipe network itself will increase when the total population increases. This sub-model also implies that the PAMSIMAS program has considered the population growth in its network calculation, e.g. calculation of the reservoir size.

\section{The Stock and Flow Diagram (SFD) of the PAMSIMAS}

SFD consists of stocks, flows, and auxiliary variables. Stocks are variables that are accumulated or depleted over time, e.g., "water board finance" and "village population", while a flow is the rate of change of the input and output in a stock variable. Auxiliary variables are other components besides stocks and flows that simplify the communication and improve the clarity of the model [13]. Auxiliary variables include (1) constant, e.g., "community characteristics"; (2) exogenous input for the stock variable, e.g., "external contribution"; (3) functions, e.g., "budget to environmental conversion"; and (4) intermediate variables, e.g., "community development". The SFD was developed from the CLD. Figure 6 shows the SFD of the PAMSIMAS.

\subsection{SFD's Model Specification}

The constants used in the SFD model were estimated using actual information from the study area. For example, information about water fee paid by PAMSIMAS beneficiaries, incentives to the water board, and O\&M costs are obtained from some PAMSIMAS projects in Magelang Regency, and this information employed to develop the equation in stock "water board finance". In addition, the information about the frequency of accidental damage in the pipe system and the percentage of water loss was used to develop the equation related to water loss due to damage. The equations used in the SFD model can be obtained in the Supplementary Materials. The CLD and SFD were developed using the Vensim Pro software package [28]. Initial values of some variables in the baseline conditions can be found in Table 1 . Non-linear variables, e.g., "Percentage of beneficiaries who pay water fee", "Environmental degradation", "Pipe network growth", and "Drought in the dry season", use lookup function (see Supplementary Materials). Using the lookup function, we could define the relationship between a variable (output $y$-axis) and its causes (input $x$-axis). For example, we made monthly variations ( $x$-axis) of the variable "drought 
in dry season" ( $y$-axis) using the lookup function. The lookup function graphs were made in such a way as to hypothetically reflect the relationship between variable A and B. For example, the relationship between variables "community development" and "percentage of beneficiaries who pay water fee" could not be defined in a mathematical equation. Therefore, we created a lookup function graph that portrays that the better the community development is, the higher the percentage of the beneficiaries who pay the water fee is.

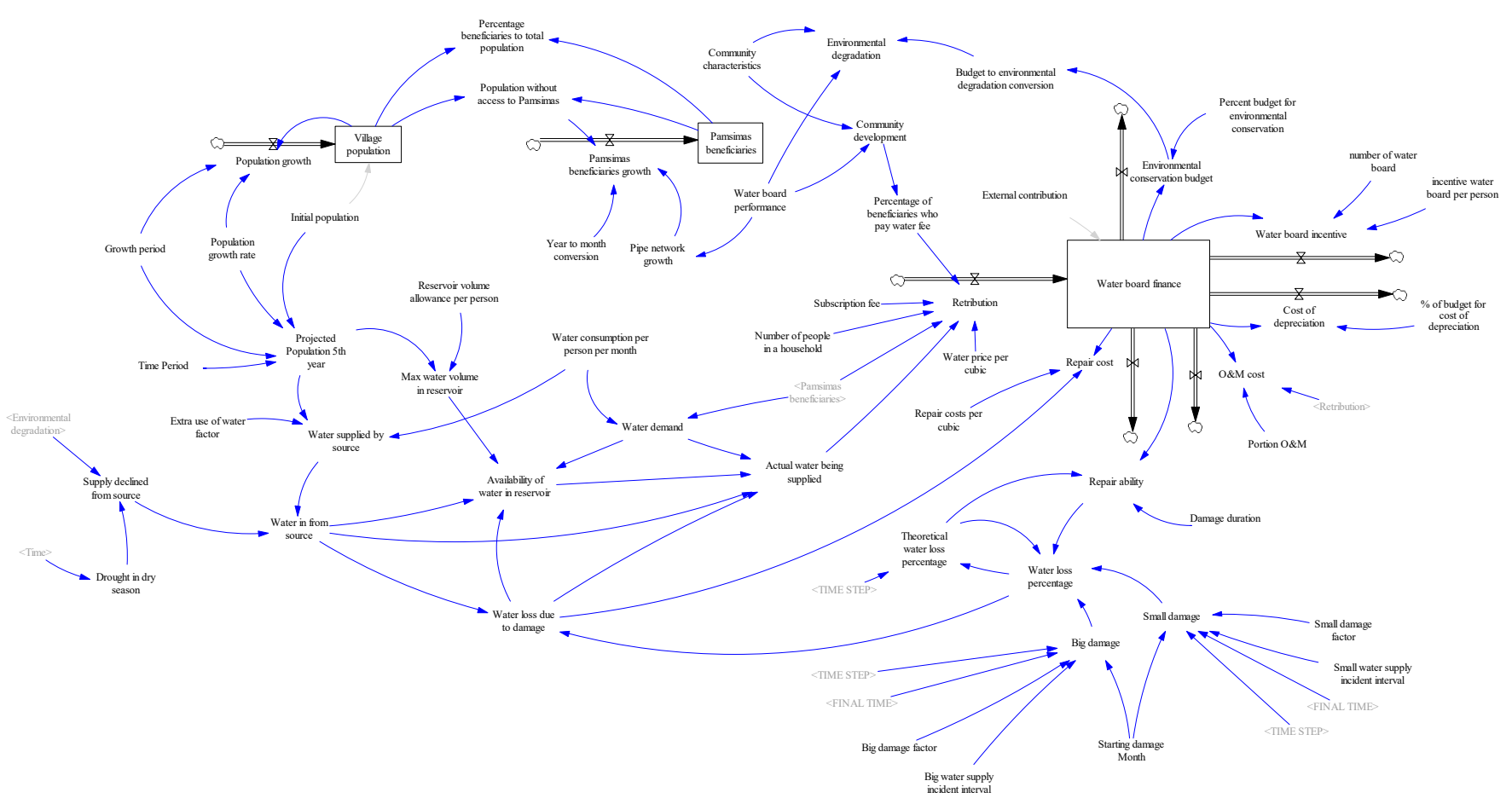

Figure 6. Stock and flow diagram of the rural water supply network (PAMSIMAS).

Table 1. Initial values of variables in the baseline conditions.

\begin{tabular}{|c|c|c|c|c|c|}
\hline Variable & Unit * & Value & Variable & Unit & Value \\
\hline Initial population & Person & 1250 & Repair cost $/ \mathrm{m}^{3}$ & $\mathrm{Rp}$ & 100 \\
\hline Population growth rate/year & Dmnl & $0.9 \%$ & External contribution & $\mathrm{Rp}$ & $5 \times 10^{6}$ \\
\hline $\begin{array}{c}\text { Number of people in a } \\
\text { household }\end{array}$ & Person & 5 & Community characteristics & Dmnl & 3 \\
\hline $\begin{array}{c}\text { Water } \\
\text { consumption/person/month }\end{array}$ & $\mathrm{m}^{3}$ & 21 & Water board performance & Dmnl & 4 \\
\hline Subscription fee/month & $\mathrm{Rp}$ & 2000 & Damage duration & Month & 1 \\
\hline Water price $/ \mathrm{m}^{3}$ & $\mathrm{Rp}$ & 1000 & Small damage factor & Dmnl & 0.15 \\
\hline $\begin{array}{l}\% \text { of budget for } \\
\text { environmental conservation }\end{array}$ & Dmnl & $\begin{array}{l}8 \% \text { of the water } \\
\text { board finance }\end{array}$ & Big damage factor & Dmnl & 0.90 \\
\hline Number of water board & Person & 5 & Small water supply incident interval & Month & 6 \\
\hline Incentive water board/person & $\mathrm{Rp}$ & 100,000 & Big water supply incident interval & Month & 24 \\
\hline $\begin{array}{c}\% \text { of budget for cost of } \\
\text { depreciation }\end{array}$ & Dmnl & $\begin{array}{l}40 \% \text { of the water } \\
\text { board finance }\end{array}$ & Extra use of water factor & Dmnl & 1.2 \\
\hline Portion O\&M & Dmnl & $\begin{array}{l}20 \% \text { of the } \\
\text { monthly fee }\end{array}$ & $\begin{array}{l}\text { Reservoir volume allowance } \\
\text { per person }\end{array}$ & $\mathrm{m}^{3}$ & 0.09 \\
\hline
\end{tabular}

${ }^{*}$ Dmnl = Dimensionless; Rp = Rupiah; $\$ 1 \approx$ Rp. 14,000. 
Variables "community characteristics" and "water board performance" have a scale from 1 (very bad) to 5 (very good). A value of " 3 " for "community characteristics" was used in the baseline condition representing a community that is "quite" cooperative and supportive, while a value of " 4 " for "water board performance" means that the performance is "good". The model was simulated for 120 months.

A stock "water board finance" is the main key performance indicator (KPI) variable in the model. We reason that a sustained community-based rural water supply is required to have a sufficient budget, i.e., budget is not zero, to perform all water board tasks. There are two inputs to stock WBF: (1) revenue, which comprises of the monthly subscription fee and water price, and (2) external contribution, which is usually provided only once at the beginning of the project, e.g., by the village office and external donors. The outputs of the stock are various costs, including "water board incentive", "cost of depreciation", "O\&M cost", "repair cost", and "environmental conservation budget". The proportion for each expense was estimated from the prevalent practice in the study area. The amount of "O\&M cost" is counted from the percentage of the total monthly revenue. There is no fixed budget for the "repair cost" because it depends on the damage and, hence, we made an assumption that the cost is Rp. 100 or $10 \%$ of the water price (see Table 1).

There is a maximum water volume that is inside the reservoir at any one time and that depends on the size of the concrete reservoir, e.g., $20 \mathrm{~m}^{3}$. The excess water is discharged into nature. The reservoir size is calculated by considering the estimated population in the fifth year and $20 \%$ of the total daily water consumption.

A variable "drought in the dry season" is related to the environmental aspect representing the effect of the surrounding environment, i.e., climate change or anomaly, on the capacity of the water source to supply water. A lookup function was used to set the drought value variation on each month (Figure 7). The drought pattern was made by considering the rainfall pattern and the average percentage of water reduction during the rainy and dry seasons in the Magelang regency. The dry season usually occurs between May and October. "Damage duration" and "small damage factor" are related to the technical aspect. The former represents the duration to fix any damage in the system, while the latter represents the percentage of water loss due to small accidental damage in the system. Lastly, the variable "community characteristics" is related to the social aspect representing the behavioural aspect and attitude of the community towards the PAMSIMAS project, e.g., whether or not the community is cooperative and supportive. However, we realised that some variables are related to more than one FIETS aspect, e.g., "O\&M cost" and "repair cost" are also related to the technical aspect besides the financial aspect.

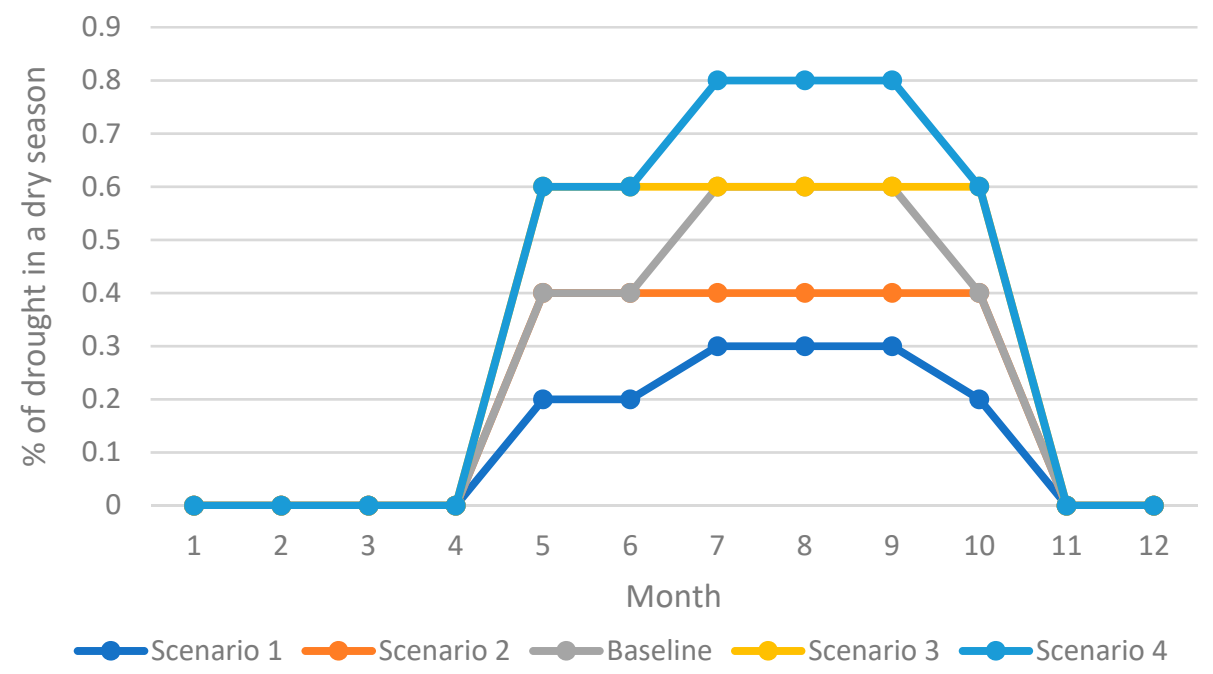

Figure 7. The lookup function of variable "drought in the dry season". 


\subsection{SFD's Model Verification}

Prior to being applied in the scenario analysis, the model was tested through three tests: model debugging, model verification, and model validation [29]. Model debugging was performed by checking and correcting errors that hinder the model from working properly, such as the erroneous equation. Model verification aims to check the model's consistency. It was conducted by checking the unit consistency and testing sub-models and structure. The SFD model passed the model debugging and verification process, i.e., there is no equation error and unit inconsistency.

Model validation aims to identify the confidence bound in the model performance. This was conducted by confirming the structure with theory or expert, testing the model under extreme conditions, and behaviour test. The first test was conducted among authors since authors are familiar with PAMSIMAS projects. For the second validation test, the model was tested by drastically change variables related to key stocks in the system, e.g., the initial population, number of the water board, and water consumption per person per month. The behaviour test is conducted to see whether the model outputs correspond to real-world behaviour or expectation.

The validation test of the extreme conditions indicated that the model outputs behave as the general hypothesis, thereby confirming the model validity. For example, (1) drastically changing the initial population drastically increased the water board finance, and (2) increased the number of water boards or the monthly incentive would drastically decrease the water board finance.

In the behaviour test, the patterns of the stock "water board finance" in baseline conditions were checked (Figure 8). The baseline graph shows that the budget decreased in the first year from the initial budget, Rp. 5,000,000 $(\approx \$ 357)$. This initial budget was obtained from the external contribution at the beginning of the project. This decrease could be explained by the regular expenses despite the low income or revenue because the piped system was still being built. After the sixth month, the financial condition increases and becomes stable at around 2 million Rupiah $(\approx \$ 142)$. The amount of water board finance is in the range of the PAMSIMAS projects in the Magelang Regency for fairly similar conditions, e.g., water price, subscription fee, initial population, etc. The fluctuation in the graph is due to the variation of the water supply in a year, i.e., dry and rainy seasons and accidental small and big damages. There are four valleys, i.e., the finance goes down sharply, in the graph which indicate the occurrence of big damage every 24 months. The finance goes down because the revenue is parallel to the amount of water being supplied to the community. Figure 8 indicates that $47 \%$ of the targeted population has access to the piped system in the first year, and this reaches $95 \%$ in the fifth year, which is fairly similar to the common conditions in the Magelang Regency. The developed model was then considered sufficient to serve the research purpose.

\subsection{Scenario Analyses}

Scenario analyses were simulated upon model validation to see the pattern of the related key performance indicator variables in some scenarios. We modified eight variables related to FIETS aspects, one at a time, and compared the results with the baseline conditions in Table 1. The input parameters for all scenarios are shown in Table 2. For example, we manually changed the input value in the variable "water board performance" from 1, 2, 3, 4, and 5 (from very bad to very good). We then compared the results in the KPI variable or stock "water board finance". The variation of the values represents worse or better conditions of that variable.

We chose variables that can be translated into practical recommendations in the field. Variables "external contribution", "O\&M cost" (operation and maintenance), and "repair cost" are related to the financial aspect. A variable "Water board performance" is related to the institutional aspect representing the overall performance of the water board in carrying out their jobs and responsibilities. All these patterns were then translated into policy recommendations to sustain the PAMSIMAS project. 

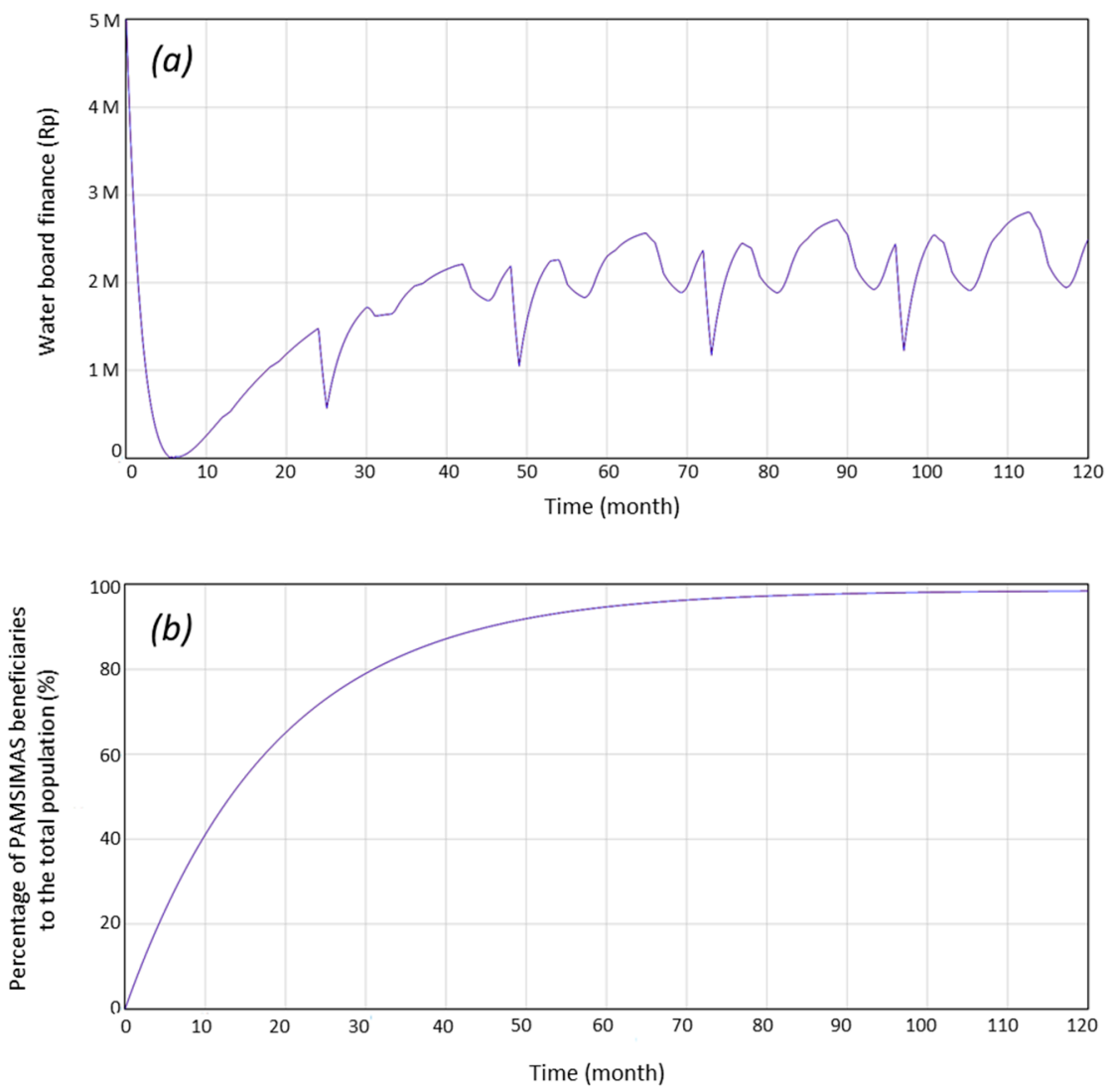

Figure 8. The stocks: (a) water board finance and (b) percentage of PAMSIMAS beneficiaries compared to the total population in baseline conditions. Simulation is for 120 months.

Table 2. Input parameters for the simulation of scenario analyses.

\begin{tabular}{|c|c|c|c|c|c|c|c|c|}
\hline Scenarios & $\begin{array}{c}\text { External } \\
\text { Contribution } \\
\left(\times 10^{6}\right)(\mathbf{R p})\end{array}$ & $\begin{array}{c}\text { Portion O\&M } \\
\text { Cost } \\
\text { (dmnl) }\end{array}$ & $\begin{array}{l}\text { Repair Cost } \\
\text { per Cubic } \\
\left(\mathrm{Rp} / \mathrm{m}^{3}\right)\end{array}$ & $\begin{array}{l}\text { Water Board } \\
\text { Performance } \\
\text { (dmnl) }\end{array}$ & $\begin{array}{l}\text { Drought in } \\
\text { the Dry } \\
\text { Season (dmnl) }\end{array}$ & $\begin{array}{l}\text { Damage } \\
\text { Duration } \\
\text { (month) }\end{array}$ & $\begin{array}{c}\text { Small } \\
\text { Damage } \\
\text { Factor (dmnl) }\end{array}$ & $\begin{array}{l}\text { Community } \\
\text { Characteristics } \\
\text { (dmnl) }\end{array}$ \\
\hline $\begin{array}{c}\text { Baseline } \\
1\end{array}$ & $\begin{array}{c}5 \\
2.5,5,7.5,10,15\end{array}$ & 0.2 & 100 & 4 & Lookup & 1 & 0.15 & 3 \\
\hline 2 & & $\begin{array}{c}0.05,0.1,0.2 \\
\quad 0.3,0.4\end{array}$ & & & & & & \\
\hline 3 & & & $\begin{array}{c}50,100,200, \\
500,750\end{array}$ & & & & & \\
\hline 4 & & & & $1-5$ & & & & \\
\hline 5 & & & & & Lookup & & & \\
\hline 6 & & & & & & $0.5,1,2,3,6$ & & \\
\hline 7 & & & & & & & $0.05,0.1,0.15$, & \\
\hline 8 & & & & & & & & $1-5$ \\
\hline
\end{tabular}

$\mathrm{dmnl}=$ dimensionless; empty cells mean that the values are similar to the baseline conditions .

The results of the scenario analyses are shown in Figure 9. Overall, all patterns confirmed the general hypothesis that better conditions or scenarios result in higher water board finance, e.g., the lower the "repair cost", the higher the water board finance is (Figure 9c).

The pattern shows that external fund contributions at the beginning of the PAMSIMAS project affect it only at the beginning of the project. Higher external contributions will support the water board finance to stay positive at the beginning of the project. The results of all scenarios of external contribution are similar after the tenth month or when about $40 \%$ of the targeted population have access to the piped system. 

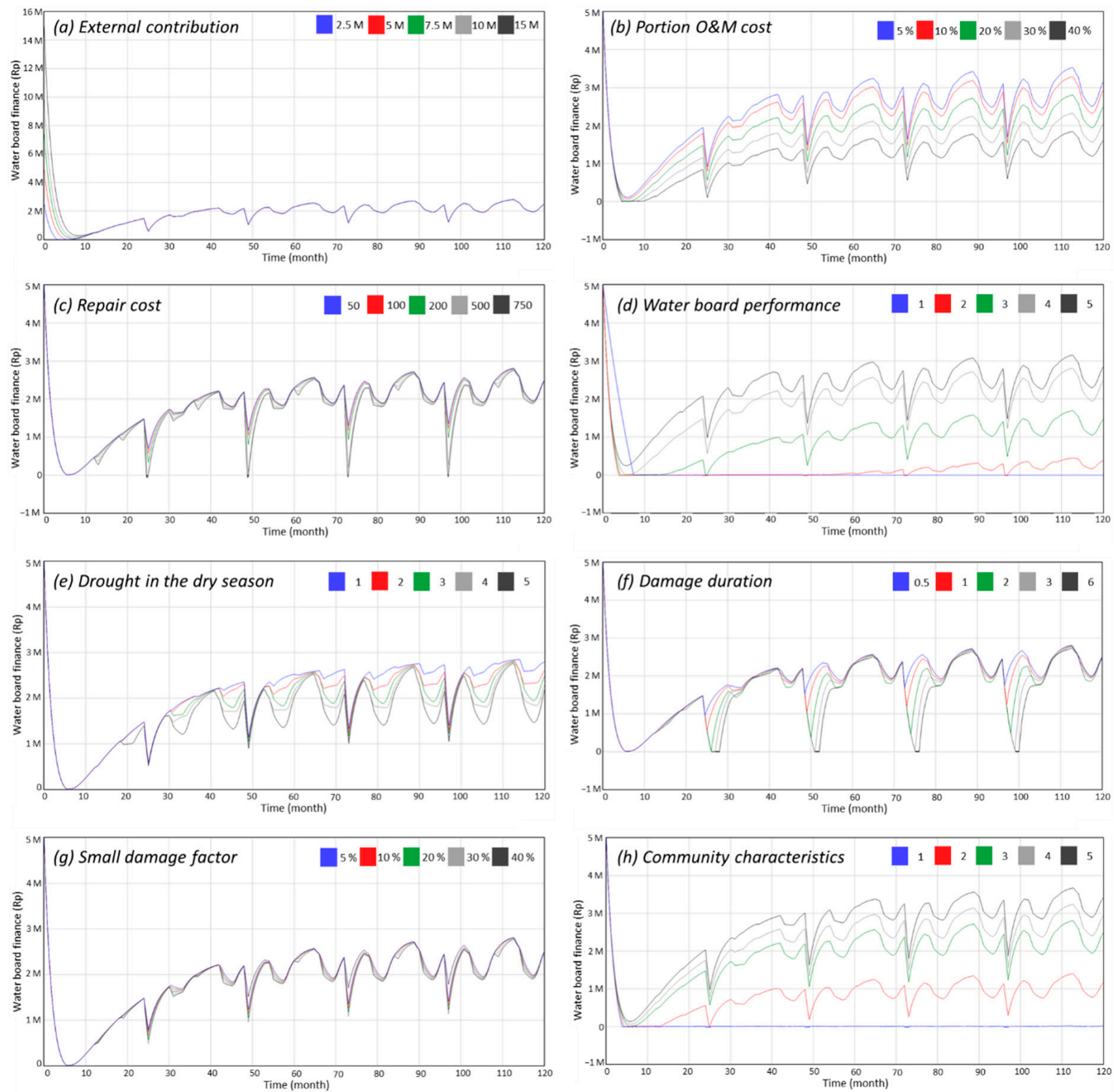

Figure 9. Implications of various scenarios of eight variables (a-h; see Table 2$)$ on water board finance. Simulation is for 120 months.

Scenarios in variables "water board performance $=1$ " and "community characteristics $=1$ " keep the water board finance zero for ten years, which is not found in other variables scenarios. The effect of water board performance is more prominent in the low score, i.e., score 1 and 2 generate almost zero finance, while the effect of community characteristics is in the high score, i.e., score 5 results in finance of more than 3 million Rupiah. These patterns indicate that human factors are critical for a successful PAMSIMAS project in Indonesia. The water board performance is critical to keeping the finance above zero Rupiah, while community characteristics are also important for maintaining a higher financial condition.

The CLD structure indicates that water board performance is critical for the pipe network growth (Figure 5). The "percentage beneficiaries to total population" graph (Figure 10a) confirmed this relationship, i.e., the higher the score of water board performance, the more people have access to piped water. 
(a) "Percentage benefiaris to total population" graph in

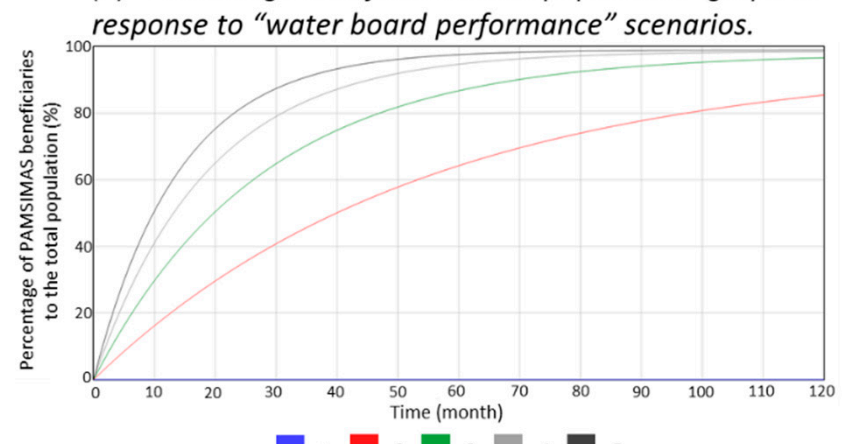

${ }_{1} \square{ }_{2} \square{ }_{3} \square_{4} \square$

(c) "Actual water being supplied" graph in response to "small damage factor" scenarios.

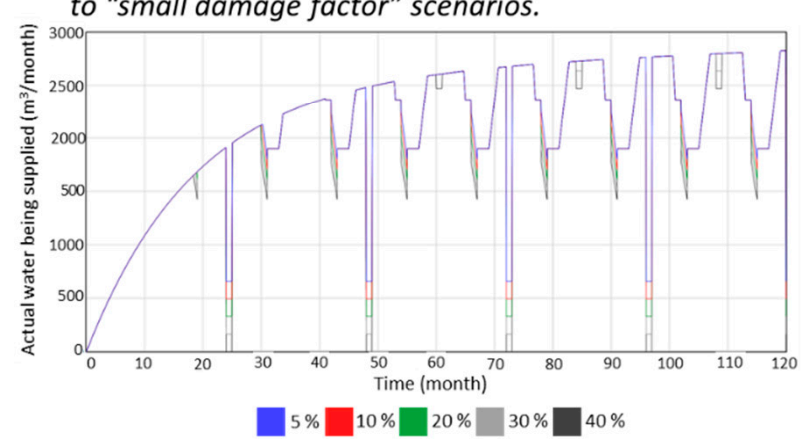

(b) "Supply decline from source" graph in response to "community characteristics" scenarios.

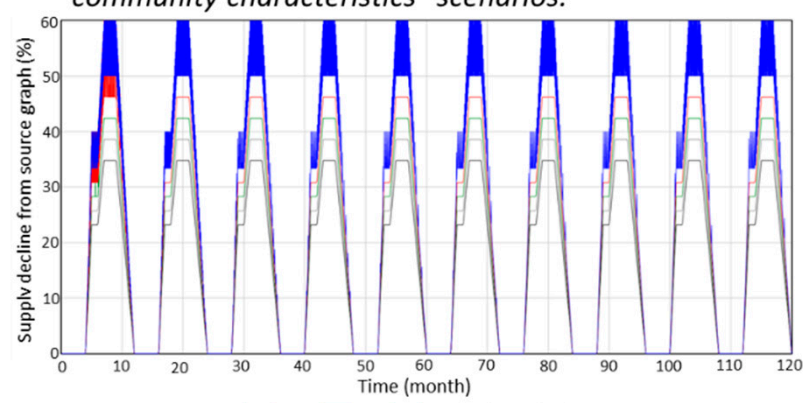

${ }_{1} \square \square^{2} \square{ }^{3} \square 5$

(d) "Actual water being supplied" graph in response to "drough in the dry season" scenarios.

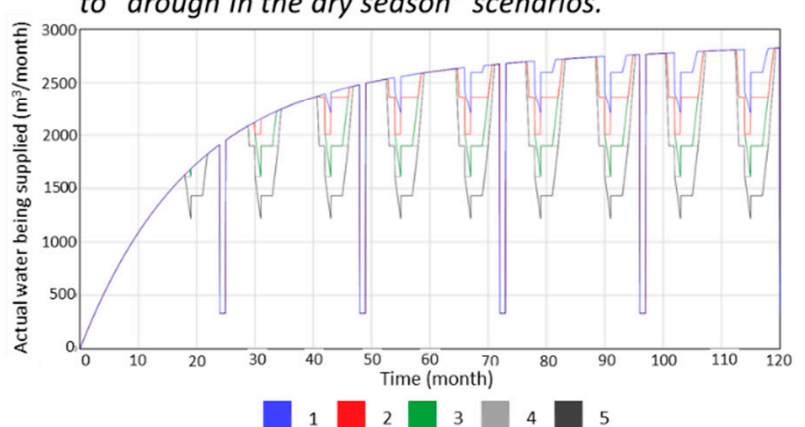

${ }_{1} \square_{2}{ }_{3}{ }_{4}{ }_{5}$

Figure 10. Implications of various scenarios (see Table 2). Simulation is for 120 months.

There is also an influence of community characteristics on environmental conservation in the system. Figure 10b implies that the higher the score of community characteristics, e.g., they are proactive to conserve the water recharge area, the lower the reduction of water supply in the dry season is.

Figure $9 f$ shows that the longer the damage period, the lower the water board finance is. This can be explained by the smaller volume of water being supplied due to water loss. This indicates that the water board cannot delay the repair procedure in the system. The simulation also shows that bigger damage will reduce the water being supplied (Figure 10c) and water board finance (Figure 9g). Furthermore, drought in the dry season and the water being supplied was inversely related, i.e., the actual water supplied is lower if the level of drought increase (Figure 10d) and then will decrease the water board finance (Figure 9e).

\subsection{Sensitivity Analysis}

Finally, the Monte Carlo univariate sensitivity analyses with 200 simulations were conducted to see the effect of changes in parameters or input values on the model's output and identify the most influential variable. Variable "drought in the dry season" was not used because a variable with the lookup function cannot be included in the sensitivity analysis in the VENSIM software. The min and max values of the sensitivity analysis were $25 \%$ of the initial value, e.g., the min-max values of variable "repair cost per cubic" is 75 and $125 \mathrm{Rp} / \mathrm{m}^{3}$, respectively, which is $25 \%$ of the initial value $=100 \mathrm{Rp} / \mathrm{m}^{3}$.

From the sensitivity analysis, we found that variable "water board performance" is the most sensitive variable, i.e., it is shown by the graph with the widest band, followed by a variable "community characteristics", while other variables have a relatively small effect on the "water board finance" (Figure 11). Therefore, "water board performance" was the "leverage point" in the system, i.e., a variable where small changes can result in big changes in the system [30], and these need more priority in the PAMSIMAS project. 

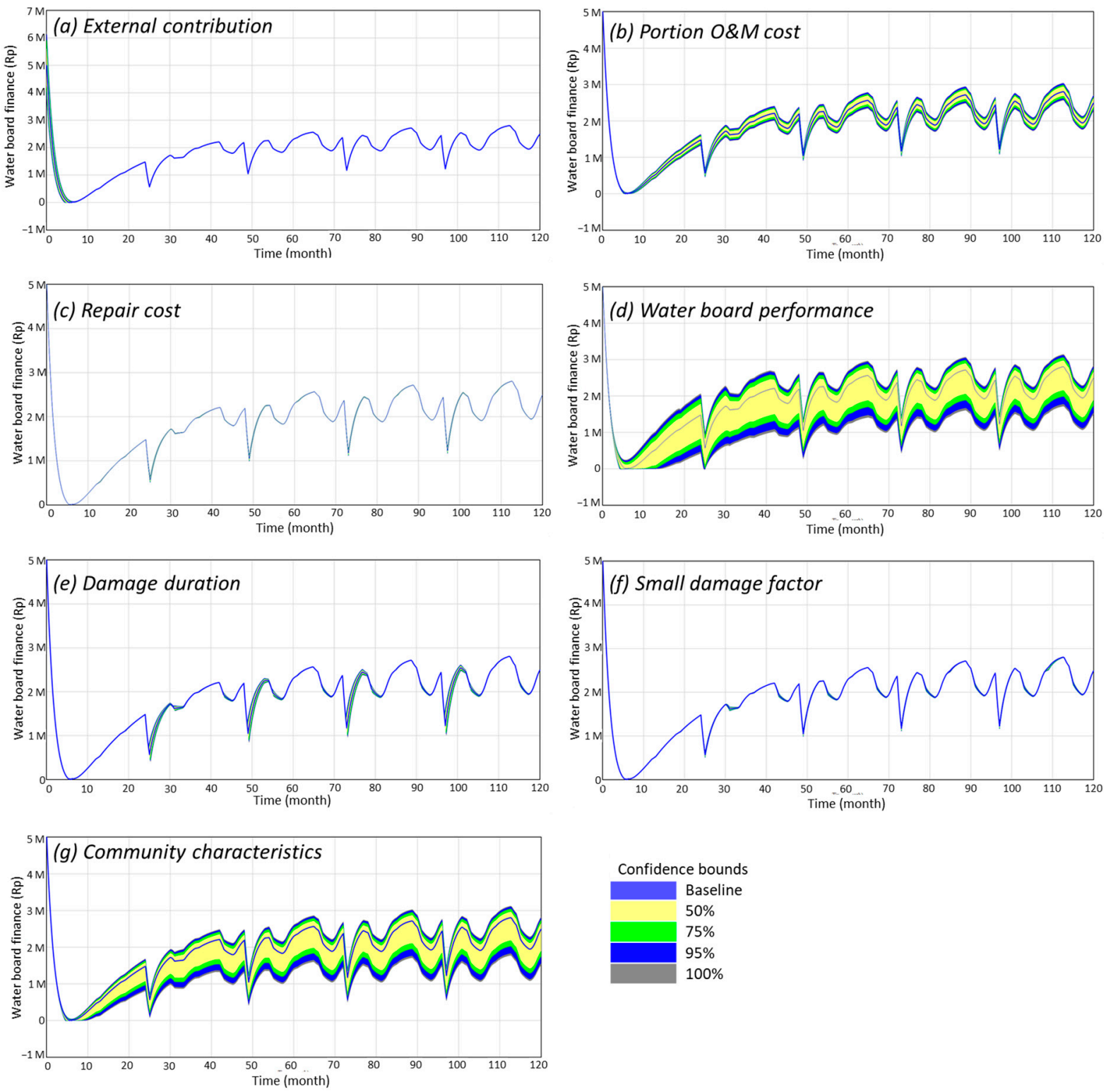

Figure 11. Monte Carlo sensitivity analysis results for seven variables (a-g) on water board finance. Simulation is for 120 months.

\section{Implications}

To the best of our knowledge, this is the first study that simulates the dynamic relationship of a rural water supply program in developing countries by considering the FIETS sustainability aspects. This study contributes to the application of the system thinking approach in the WASH domain. Furthermore, since all PAMSIMAS programs follow a similar approach, the dynamic behaviour and practical recommendations of this model may represent all PAMSIMAS programs in Indonesia, e.g., the supply from water source decrease during the dry season and community characteristics positively influence the water board finance.

Furthermore, we argue that visualising relevant sustainability factors in the CLD and SFD allows us to understand a big picture view of the situation, e.g., to understand how factors are interconnected, and the possible behaviour or pattern of the system given some scenarios. This visualisation is important to help people from different backgrounds, technical levels, or education to comprehend the complexity behind the rural water supply system in their area [31]. 
Table 3 summarises policy or practical recommendations translated from the scenario analyses. Each practical recommendation could be used on a check-list or best practices guideline for community-based rural drinking water supply programs, not only in Indonesia but in other developing countries.

Table 3. Practical recommendations to PAMSIMAS project.

\begin{tabular}{ccl}
\hline Variables in the System & Sustainability Aspect & \multicolumn{1}{c}{ Practical Recommendations } \\
\hline External contribution & Financial & Look for external fund contribution, CSR funds from industry \\
Portion O\&M & Financial, technical & - $\begin{array}{l}\text { Plan and implement O\&M at an affordable price level for } \\
\text { the community. } \\
\text { Prioritise the O\&M on critical or prone points in the system, } \\
\text { especially if the budget is limited. }\end{array}$ \\
& Use locally available spare parts.
\end{tabular}

Repair cost per cubic Financial, technical

- Implement cost-effective repair methods, e.g., use cheaper (but still good quality) alternative spare parts.

- Select competent, passionate, and incorruptible water

Water board performance Institution board members.

- Conduct regular training and mentoring by the PAMSIMAS district facilitator.

\begin{tabular}{|c|c|c|}
\hline Drought in the dry season & Environmental & $\begin{array}{l}\text { - Make a rotation schedule for water collection in the dry season. } \\
\text { Implement and promote water-saving, especially during the } \\
\text { dry season. }\end{array}$ \\
\hline Damage duration & Technical & - Repair damage as soon as possible. \\
\hline Small damage factor & Technical & $\begin{array}{l}\text { - Make a list of potential causes of accidental damage and apply } \\
\text { relevant protections in the system. }\end{array}$ \\
\hline Community characteristics & Social & $\begin{array}{l}\text { - Involve the community in the whole PAMSIMAS process. } \\
\text { - Conduct behavioural intervention. }\end{array}$ \\
\hline
\end{tabular}

According to the system approach perspective, each factor plays its role in the system, and ignoring one aspect of them will hinder the sustainability of the water services. This emphasizes the need for improving the whole system [14]. However, since many factors are related to the water board, e.g., external contribution, portion O\&M, water board performance, etc., we confirm a previous study arguing that strong community institutions (mainly referring to water board performance) are necessary to keep the piped system functioning over time [32,33]. Mentoring of the village water board by the PAMSIMAS district facilitator could be an option to ensure that the water board has sufficient capacity to efficiently manage the piped system, e.g., repair broken piped or implement cost-effective O\&M [20].

In the case of the PAMSIMAS program, we highlight the need to find passionate water board members. Individual or group performance is influenced by their motivation to conduct their jobs, as indicated in another context outside water [34]. We argue that this issue, i.e., passionate water board members, is critical since there are many PAMSIMAS programs 
not paying the water board members, i.e., the village water board work voluntarily, which is mainly due to insufficient water board finance.

This study also indicates that the PAMSIMAS project needs external funding support to prevent lack of money in the water board's finances. External funding support has been mentioned as critical to sustaining the rural water supply program $[35,36]$. This is especially useful at the beginning of the project, i.e., when the system is still being built and revenue is low. In the case of PAMSIMAS, the water board is responsible for looking for external funds. Therefore, the issue of passionate water board members becomes critical. An example of the external fund is corporate social responsibility (CSR) funds from industry. CSR funds have been used on some occasions in Indonesia to develop a piped water system in a village [37]. Another suggestion is to transform the village water board into one of the business units of the village-owned enterprises, so-called BUMDES in Bahasa, with the aim that the water board can be managed professionally, get fixed financial supports from the village, and generate profit $[38,39]$. However, this transformation should be carefully conducted as it is prone to conflict of interest [40].

The model also simulates the important role of the community in sustaining the rural drinking water supply program, as also mentioned by other studies [23]. Community involvement and empowerment are necessary to make sure the beneficiaries or target group fully support the project to increase the sense of ownership and then willingness to contribute financially [10].

Another important community factor is the behavioural aspect. A previous report mentioned that many WASH programs in Indonesia failed due to an infrastructure-centric approach that ignores the behavioural aspect of the target group [6]. A behavioural change promotion is actually one of the initial activities of the PAMSIMAS program before the construction of the piped distribution system. However, ineffective promotion often occurs because of the rush to immediately construct the system. Hence, we highlight the importance of appropriate and effective behavioural intervention before starting the PAMSIMAS project.

Kelly et al. [41] mention the importance of considering the seasonal changes, i.e., dry and rainy season, in availability and water demand in the rural water supply system. They found that a system breakdown often occurs in the rainy season (which affects the water availability), and people change the water source depending on the season, which influences the water board finance (water demand). However, our model only focuses on the variation of water availability, especially in the dry season, i.e., according to the variable "drought in the dry season". The PAMSIMAS program actually considers the seasonal variation of the water source used, i.e., it takes into account the water reduction in the dry season. However, human factors, i.e., land use and environmental destruction surrounding the water source or recharge area, often worsen the situation. Therefore, as also implied in our model structure, the water board and community have to be proactive in protecting the environment around the water source or recharge area to minimize the water reduction in the water source.

Previous studies indicate that having a good financial scheme and management is crucial to sustaining rural water supply programs $[10,32]$. This includes designing costeffective O\&M and repair. However, obtaining original and high-quality spare parts in isolated or remote areas is often challenging. There is an inequality of economic growth and goods distribution due to geographical and infrastructure variation in Indonesia [42]. This situation results in high prices for spare parts for O\&M and repair. Therefore, innovations using locally available spare parts, e.g., not original but of a good quality, are critical to reducing the O\&M and repair costs, especially in isolated or remote areas.

There are some recommendations for future research. First, seasonal variation of the water source used by the community should be further modelled when we talk about water supply in rural areas since studies have found that people may change their water source seasonally $[41,43]$. Second, expanding the model by including WASH-related behaviour variables, such as household water treatment practice, use of sanitation facility, and hand- 
washing behaviour, could help us to better understand the dynamic influence of the piped water supply on those behaviours. Third, there is a need to deeply analyse the effect of non-linear variables, such as water board performance or community characteristics, on the overall system behaviour, which then can improve and validate the model.

\section{Conclusions}

This study demonstrates the application of system dynamics in explaining the sustainability of the water supply system in developing countries using a case study in the Magelang Regency in Indonesia. The illustration of the inter-linked factors influencing the sustainability of a community-based rural drinking water supply program in Indonesia was shown by the causal loop diagram. Furthermore, the stock and flow diagram simulates the dynamic relationship among those factors. Scenario analyses using 8 variables related to financial, institutional, environmental, technical, and social sustainability aspects were conducted. Through the scenario and sensitivity analyses, we found that the water board plays a significant role in accelerating pipe network growth and sustaining the PAMSIMAS program. Furthermore, we suggest that the water board look for external funds to support the program at the early stage. Based on the simulation, community involvement and empowerment positively influenced the continuity of the PAMSIMAS program. Finally, this paper has revealed the complexity of the water supply system in developing countries, particularly in Indonesia. Unravelling this kind of complex system via a clear visualisation of each variable's interconnectedness and via quantitative simulations is necessary for raising the awareness of all related stakeholders, such as water board, policymakers, and the community, so as to design and implement a better water supply program in their area.

Supplementary Materials: The following are available online at https:/ / www.mdpi.com/2073-444 $1 / 13 / 4 / 507 /$ s1, Equations, constants, and units in the PAMSIMAS model.

Author Contributions: Conceptualization, D.D. and J.P.; methodology, D.D., J.P., T.P.A.D., and A.P.; software, D.D. and J.P.; validation, D.D., J.P., S.S., and T.P.A.D.; formal analysis, D.D. and J.P.; investigation, D.D. and J.P.; resources, D.D. and J.P.; data curation, D.D., T.P.A.D., and S.S.; writingoriginal draft preparation, D.D.; writing - review and editing, D.D., J.P., T.P.A.D., A.R., S.S., and A.P.; visualization, D.D.; project administration, T.P.A.D. and S.S. All authors have read and agreed to the published version of the manuscript.

Funding: This research received no external funding.

Institutional Review Board Statement: Not applicable.

Informed Consent Statement: Not applicable.

Data Availability Statement: Data is contained within the article or Supplementary Material.

Conflicts of Interest: The authors declare no conflict of interest.

\section{References}

1. UNICEF; WHO. Progress on Household Drinking Water, Sanitation and Hygiene 2000-2017: Special Focus on Inequalities; UNICEF and WHO: New York, NY, USA, 2019.

2. WHO; UNICEF. Safely Managed Drinking Water-Thematic Report on Drinking Water 2017; World Health Organization: Geneva, Switzerland, 2017; Available online: https://data.unicef.org/resources/safely-managed-drinking-water/ (accessed on 23 November 2020).

3. Kummu, M.; Guillaume, J.H.A.; De Moel, H.; Eisner, S.; Flörke, M.; Porkka, M.; Siebert, S.; Veldkamp, T.I.E.; Ward, P.L. The world's road to water scarcity: Shortage and stress in the 20th century and pathways towards sustainability. Sci. Rep. 2016, 6, 38495. [CrossRef] [PubMed]

4. Kasri, R.Y.; Wirutomo, P.; Kusnoputranto, H.; Moersidik, S.S. Citizen engagement to sustaining community-based rural water supply in Indonesia. Int. J. Dev. Issues 2017, 16, 276-288. [CrossRef]

5. Wray, E. Indonesia: Expanding Access to Clean Water for the Rural Poor. World Bank. 2019. Available online: https: //www.worldbank.org/en/results/2019/07/29/indonesia-expanding-access-to-clean-water-for-the-rural-poor (accessed on 13 September 2020).

6. The World Bank. PAMSIMAS: Responding to the Water and Sanitation Challenges in Rural Indonesia; World Bank Publication: Jakarta, Indonesia, 2014. 
7. Carrard, N.; Willetts, J. Environmentally sustainable WASH? Current discourse, planetary boundaries and future directions. J. Water Sanit. Hyg. Dev. 2017, 7, 209-228. [CrossRef]

8. Kamulyan, P.; Wiguna, I.P.A.; Slamet, A. Penilaian Keberlanjutan Pengelolaan Sistem Penyediaan Air Minum Berbasis Masyarakat Di Kota Blitar. J. Civ. Eng. 2018, 32, 60. [CrossRef]

9. Dutch WASH Alliance. FIETS Sustainability Approach; Dutch WASH Alliance: Haarlem, The Netherlands, 2013.

10. Marks, S.J.; Kumpel, E.; Guo, J.; Bartram, J.; Davis, J. Pathways to sustainability: A fuzzy-set qualitative comparative analysis of rural water supply programs. J. Clean. Prod. 2018, 205, 789-798. [CrossRef]

11. Walters, J.P.; Javernick-Will, A.N. Long-term functionality of rural water services in developing countries: A system dynamics approach to understanding the dynamic interaction of factors. Environ. Sci. Technol. 2015, 49, 5035-5043. [CrossRef] [PubMed]

12. Valcourt, N.; Walters, J.; Javernick-Will, A.; Linden, K.; Hailegiorgis, B. Understanding rural water services as a complex system: An assessment of key factors as potential leverage points for improved service sustainability. Sustainability 2020, $12,1243$. [CrossRef]

13. Sterman, J. Business Dynamics: Systems Thinking and Modeling for a Complex World, 6th ed.; McGraw-Hill Education: New York, NY, USA, 2000. Available online: http:/ / books.google.se/books?id=FYCanQEACAAJ\&dq=intitle:Business+dynamics+inauthor: sterman\&hl=\&cd=4\&source=gbs_api\%5Cnhttp: / / file/ / localhost(null)\%5Cnpapers3: / / publication/uuid /E3E91541-AD34-42 2D-A772-F8E2568556E7 (accessed on 23 November 2020).

14. Valcourt, N.; Javernick-will, A.; Walters, J.; Linden, K. System approaches to water, sanitation, and hygiene: A systematic literature review. Int. J. Environ. Res. Public Health 2020, 17, 702. [CrossRef]

15. Forrester, J.W. Industrial Dynamics; MIT Press: Cambridge, MA, USA, 1961.

16. Peters, D.H. The application of systems thinking in health: Why use systems thinking? Health Res. Policy Syst. 2014, 12, 1-6. [CrossRef]

17. Purwanto, A.; Sušnik, J.; Suryadi, F.X.; de Fraiture, C. Using group model building to develop a causal loop mapping of the water-energy-food security nexus in Karawang Regency, Indonesia. J. Clean. Prod. 2019, 240, 118170. [CrossRef]

18. Purwanto, A.; Sušnik, J.; Suryadi, F.X.; de Fraiture, C. Quantitative simulation of the water-energy-food (WEF) security nexus in a local planning context in indonesia. Sustain. Prod. Consum. 2021, 25, 198-216. [CrossRef]

19. Liddle, E.S.; Fenner, R. Water point failure in sub-Saharan Africa: The value of a systems thinking approach. Waterlines 2017, 36, 140-166. [CrossRef]

20. Neely, K.; Walters, J.P. Using causal loop diagramming to explore the drivers of the sustained functionality of rural water services in Timor-Leste. Sustainability 2016, 8, 57. [CrossRef]

21. de Araujo, W.C.; Oliveira Esquerre, K.P.; Sahin, O. Building a system dynamics model to supportwater management: A case study of the semiarid region in the Brazilian northeast. Water 2019, 11, 2513. [CrossRef]

22. Palmer, C.G. Using System Dynamics to Explore the Water Supply and Demand Dilemmas of a Small South African Municipality. In Proceedings of the 32nd International Conference of the System Dynamics Society, Delft, The Netherlands, 21-24 July 2014; pp. 1-21.

23. Madrigal, R.; Alpízar, F.; Schlüter, A. Determinants of Performance of Community-Based Drinking Water Organizations. World Dev. 2011, 39, 1663-1675.

24. BPS Kabupaten Magelang. Kabupaten Magelang Dalam Angka 2020; BPS Kabupaten Magelang: Magelang, Indonesia, 2020.

25. Kurniawan, R.F. Kota Magelang Masih Hadapi Tantangan Akses Air Minum dan Pelayanan Sanitasi. Tribun Jogja. 2020. Available online: https://jogja.tribunnews.com/2020/03/11/kota-magelang-masih-hadapi-tantangan-akses-air-minum-danpelayanan-sanitasi?page=all (accessed on 15 September 2020).

26. Suyitno, H. 200 Desa di Kab Magelang Nikmati Air Bersih Pamsimas. Antara Jateng. 2020. Available online: https://jateng. antaranews.com/berita/318998/200-desa-di-kab-magelang-nikmati-air-bersih-pamsimas (accessed on 15 September 2020).

27. Djono, T.P.A. Analisis Keberlanjutan Sistem Penyediaan Air Minum Pedesaan; Universitas Indonesia: Depok, Indonesia, 2011.

28. Ventana Systems. Vensim Pro. 2020. Available online: https://vensim.com/download/ (accessed on 15 September 2020).

29. Pruyt, E. Small System Dynamics Models for Big Issues: Triple Jump towards Real-World Complexity, 2nd ed.; TU Delft Library: Delft, The Netherlands, 2013.

30. Banos-Gonzalez, I.; Martínez-Fernández, J.; Esteve-Selma, M.-Á.; Esteve-Guirao, P. Sensitivity Analysis in Socio-Ecological Models as a Tool in Environmental Policy for Sustainability. Sustainability 2018, 10, 2928. [CrossRef]

31. Kinchin, I.M.; Streatfield, D.; Hay, D.B. Using Concept Mapping to Enhance the Research Interview. Int. J. Qual. Methods 2010, 9 , 52-68. [CrossRef]

32. Machado, A.; dos Santos, J.A.N.; da Quindeler, N.S.; Alves, L.M.C. Critical Factors for the Success of Rural Water Supply Services in Brazil. Water 2019, 11, 2180. [CrossRef]

33. Daniel, D.; Djohan, D.; Nastiti, A. Sanitation, and Hygiene (WASH) Services in Rural Indonesia: Evidence from Small Surveys of WASH-Related Stakeholders in Indonesia. Water 2021, 13, 314. [CrossRef]

34. Laurence, G.A.; Fried, Y.; Yan, W.; Li, J. Enjoyment of Work and Driven to Work as Motivations of Job Crafting: Evidence from Japan and China. Jpn. Psychol. Res. 2020, 62, 1-13. [CrossRef]

35. Miller, M.; Cronk, R.; Klug, T.; Kelly, E.R.; Behnke, N.; Bartram, J. External support programs to improve rural drinking water service sustainability: A systematic review. Sci. Total Environ. 2019, 670, 717-731. [PubMed] 
36. Davis, J.; Lukacs, H.; Jeuland, M.; Alvestegui, A.; Soto, B.; Lizárraga, G.; Bakalian, A.; Wakeman, W. Sustaining the benefits of rural water supply investments: Experience from Cochabamba and Chuquisaca, Bolivia. Water Resour Res. 2008, 44. [CrossRef]

37. PAMSIMAS. Sinar Mas Group Kucurkan 3.5 M Untuk SPAM Perdesaan di Kab.Tanah Bumbu. PAMSIMAS. 2019. Available online: http:/ / new.pamsimas.org/media.php? module=detailberita\&id=2276\&cated=26 (accessed on 30 January 2021).

38. Sofyani, H.; Atmaja, R.; Rezki, S.B. Success Factors of Village-Owned Enterprises (BUMDes) Performance in Indonesia: An Exploratory Study. J. Acc. Investig. 2019, 20, 48-58. [CrossRef]

39. Mahdi, A.S.; Niswah, F. Strategi Pembangunan Desa Melalui Pamsimas (Penyediaan Air Minum Dan Sanitasi Berbasis Masyarakat) Di Desa Mentaras Kecamatan Dukun Kabupaten Gresik. Publika 2018, 6. Available online: https://core.ac. uk/reader/230720004 (accessed on 30 January 2021).

40. Mediawan, Y. Pengelolaan Manajemen Aset Program Pamsimas dan Implikasi Terhadap Kelembagaan Badan Usaha Milik Desa (Bumdesa); Kementerian pekerjaan umum dan perumahan rakyat: Jakarta, Indonesia, 2019.

41. Kelly, E.; Shields, K.F.; Cronk, R.; Lee, K.; Behnke, N.; Klug, T.; Bartram, J. Seasonality, water use and community management of water systems in rural settings: Qualitative evidence from Ghana, Kenya, and Zambia. Sci. Total Environ. 2018, 628-629, 715-721. [CrossRef]

42. Maryaningsih, N.; Hermansyah, O.; Savitri, M. The Role of Infrastructure on Economic Growth in Indonesia. Bull. Monet. Econ. Bank 2014, 17, 55-88.

43. Elliott, M.; MacDonald, M.C.; Chan, T.; Kearton, A.; Shields, K.F.; Bartram, J.K.; Hadwen, W.L. Multiple household water sources and their use in remote communities with evidence from Pacific Island countries. Water Resour. Res. 2017, 53, 9106-9117. [CrossRef] 